\title{
RECENT ACQUISITIONS: MANUSCRIPTS, TYPESCRIPTS AND PROOFS
}

Sheila Turcon

Russell Archives / McMaster University Library

Hamilton, ON, Canada L8s $4 \mathrm{~L} 6$

\footnotetext{
$\mathrm{T}$
}

he previous update of manuscript acquisitions appeared in Russell, n.s. I3 (1993): 203-5. The 2I entries here bring the total to $54 \mathrm{I}$ entries of manuscript-related acquisitions since the Russell Archives' arrival at McMaster in 1968. See the "25-Year Index" in Russell, n.s. I5 (winter 1995-96) for citations of all previous updates. Transcripts of Russell's contributions to the ввс Brains Trust programme will be appear in a future update.

The listing is by time of composition or, failing that, of publication; books are listed by date of publication. Bracketed descriptions are supplied for documents that lack titles. Bold references are to, and first publication details are from, Blackwell and Rujas Bibliography of Bertrand Russell. Publication in the Collected Papers is noted. I wish to thank the three institutions that provided McMaster with copies of original documents in their possession.

The last accession listed is Rec. Acq. I,229. "P." means photocopy; "ts.", typescript or typed, depending on the context; and "l.", letter.

[Notes found in J. B. Stallo's The Concepts and Theories of Modern Physics (London: Kegan Paul, Trench, Trübner, I89o)]. April r896 (when BR recorded reading the book). P. of ms.; 2 leaves. Courtesy of John G. Slater. Rec. Acq. I,198.

"Remarques sur la logique mathématique de M. Couturat". II July ig04. P. of ms.; 5 leaves. With 1. of 5 July 1904 to Louis Couturat. Courtesy of Bibliothèque de la Ville, La Chaux-de-Fonds, Switzerland. Rec. Acq. 422. 


$$
\text { Stont on Tratt }
$$

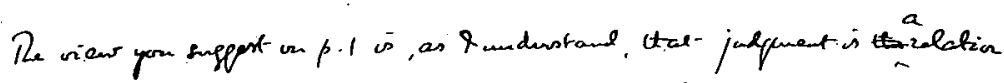

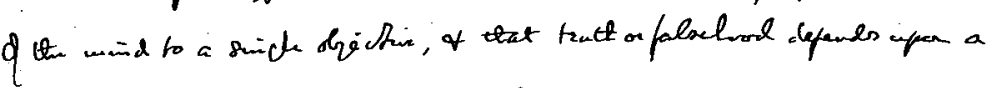

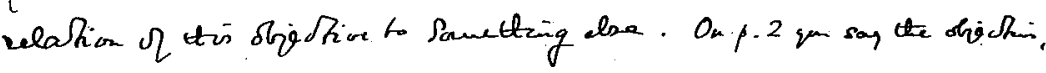

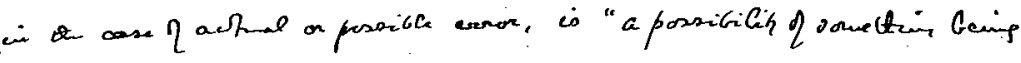

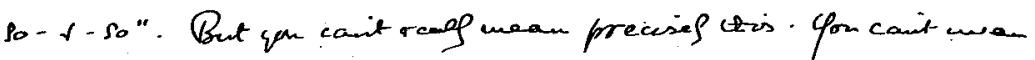

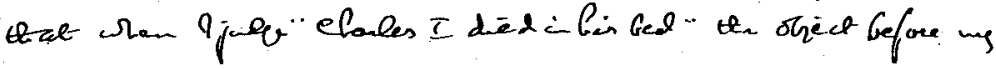

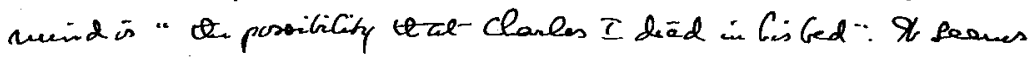

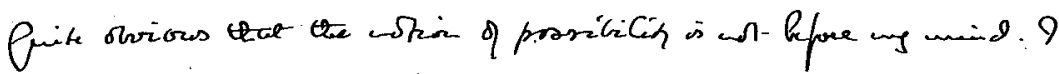

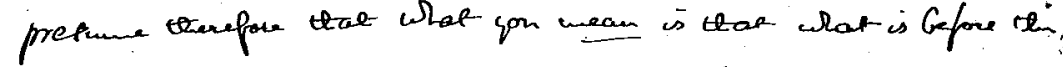

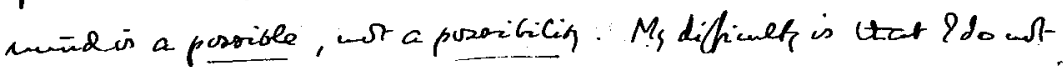

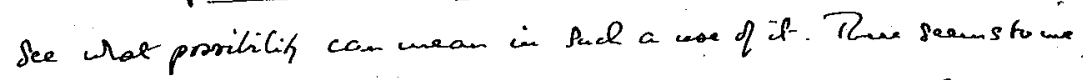

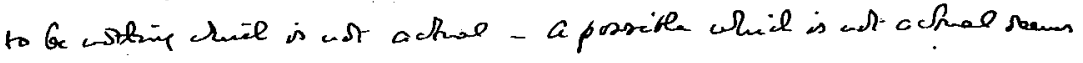

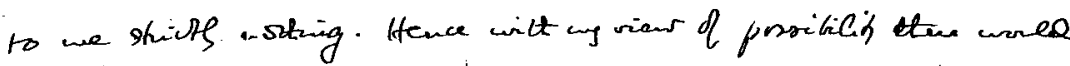

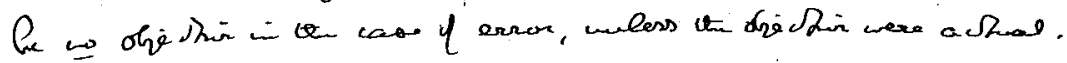

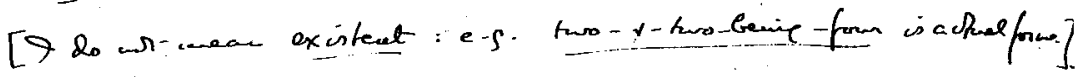

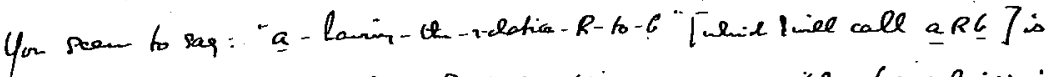

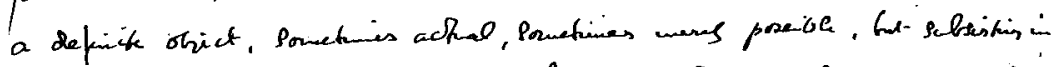

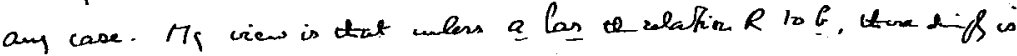
un sud tim as a RG , eittuc chal or posoill.

Folio I of "Stout on Truth" (I9II)
"Stout on Truth". Hhir.02. Ms.; 3 leaves. Ms. sent to G. F. Stout, presumably in reply to his 1 . and draft paper of 6 March I9II (RAI 7ro). (The draft paper, "Russell on the Nature of Truth", accompanies BR's ms.) Five sentences are quoted in Stout's "The Object of Thought and Real Being", Proceedings of the Aristotelian Society, n.s. II (I9IO-II): I87-205 (at 203), and his Studies in Philosophy and Psychology (1930), p. 350. Purchase from R. K. Stout. Rec. Acq. I,I90.

"Impressions of Bolshevik Russia". C20.17. Ms.; 5 leaves. "Bolshevik Theory". Ms.; 5 leaves. "Communism \& the Soviet Constitution". Ms.; 9 leaves. "Lenin and Trotsky and Gorky". Ms.; 5 leaves. "Bolshevism \& the International Situation". Ms.; 6 leaves. "Town and Country". Ms.; 5 leaves. [Addendum]. Ms.; r leaf. In The Nation, London, 27 (10, 17, 24, 31 July and 7 Aug. 1920): 460-2, 493-4, 520-I, 547-8, 576-7, and The Practice and Theory of Bolshevism (A34). Purchase from John Wilson. Rec. Acq. I, I72.

"Sketches of Modern China. r. The Feast and the Eclipse". C2r.29. Ms.; 8 leaves. "rr. Chinese Ethics". Ms.; 7 leaves. "Irr. Chinese Amusements". Ms.; 8 leaves. Galley proofs of I and III; I is corrected by BR. In The Nation and the Athenaeum, London, 30 (3, Io and I7 Dec. 1921): 375-6, 429-30, 46I-3. Purchase from John Wilson. Rec. Acq. I,I82.

"Analytic and Synthetic Philosophers". C22.ro. P. of ms.; 5 leaves. In The Nation and the Athenaeum, 3I (15 July 1922): 538-9, and Papers 9. Courtesy of John Wilson. Rec. Acq. I,I70.

The ABC of Atoms.(A45): blurb. Ms.; I leaf. 1923. Purchase. Rec. Acq. I,I7I.

[Autobiographical Sketch]. Ms.; 2 leaves. Ts. carbon; i leaf. Encl. with 1. of 2 April 1925 to Wm. Swan Stallybrass of Kegan Paul. In the 1. BR sets down the following terms: the sketch may be altered without consulting him when published it is to appear as if it is NOT by him; it is to be hoped that it will appear only outside of England. Purchased at Sotheby's. Rec. Acq. I,I7I.

"Proposed Letter to Manchester Guardian". Ps. of 2 tss. with different annotations; 4 leaves. P. of ts. carbon (different typing); 2 leaves. [1930]. Re the proposed Education Bill. Roy Randall's covering l. shows he was looking after the master text. Similar to F30.or but this one was written in response to a 1. which The Manchester Guardian published from a body of non-Conformists. Neither 1. has been located. Note: The Manchester Guardian did publish F30.or as "Education Bill and Its Critics", 27 June 1930, p. 22; the 1 . is dated 25 June. Courtesy of the International Institute of Social History. Rec. Acq. I,I85.

"Hey nonny no!" [1930]. P. of transcription ms. by BR of the anon. c. I600 verse; I leaf. Courtesy of M. G. I. Evans. Rec. Acq. I,2II.

"Analysis of Mind". B52. P. of ts.; 5 leaves sent in BR's 1. of 26 June I93I to Charles W. Morris. The ts. is annotated by Morris. Published as " 34 . 
Russell's Reformulation of the Nature of Mind" in Morris's Six Theories of Mind (Chicago: U. of Chicago P., 1932), pp. I34-8; reprinted in Papers 10. Courtesy of Jon R. Eller, Peirce Project, Indiana U. Rec. Acq. I,229.

"Modern Methods in Education". D32.02. Ts.; I2 leaves, prepared by Christina Foyle, of BR's speech at Foyle's Literary Luncheon, I4 Dec. 1932, possibly to mark the publication of Education and the Social Order (A63). The speech was reported in The Scotsman, Edinburgh, Is Dec. 1932, as well as other newspapers. Courtesy of Christina Foyle. Rec. Acq. 1,176.

We Did Not Fight. B6o. 1935. Uncorrected bound page proofs, including BR's contribution, "Some Psychological Difficulties of Pacifism in Wartime". Purchase. Rec. Acq. 1,205.

"The Existence and Nature of God". D39.04. P. of ts.; I2 leaves, identity of preparer unknown. BR's speech at the U. of Michigan, i8 Feb. 1939 . Reported in The Michigan Daily, ig Feb. 1939, pp. I, 6. Published in Papers 1o. Courtesy of U. of Michigan. Rec. Acq. I,I77.

"The Nature of Liberal Civilization". With Sidney Hook. C85.or. A "conversation" on the B BC, I Oct. I953. Ts.; 3 leaves (BR's remarks only; compare the transcription with that in Russell, n.s. 5 [1985]: 5-13). Rec. Acq. I,Iro.

"Celebrity". D5r.or. Ts.; 5 leaves, prepared by Christina Foyle, of BR's speech at Foyle's Literary Luncheon, 30 Nov. I950, to launch How to Be a Celebrity $\left(\mathbf{H}_{4} \mathbf{I}\right)$. The speech was reported in The Saturday Review of Literature, 34, no. II (I7 March 1951): 4, 5. Rec. Acq. I, I76.

[Fiction]. D53.03. Ts.; 5 leaves, prepared by Christina Foyle, of BR's speech at Foyle's Literary Luncheon, $27 \mathrm{Feb}$. 1953, to launch the publication of Satan in the Suburbs (A94). The speech was reported in The Manchester Guardian, 28 Feb. 1953, p. 4, as well as other newspapers. Courtesy of Christina Foyle. Rec. Acq. 1,176.

"Message to Be Read at the Meeting on April 30, 1957, of the National Council for the Abolition of Nuclear Weapon[s] Tests". C57.17. P. of ts.; I leaf. In Peace News, London, no. 1,088 (3 May 1957): 3. Courtesy of CND. Rec. Acq. I, 203

[“A Message from Earl Russell”]. C59.ıra. P. of ts.; I leaf. This message appeared in an advertisement for the CND meeting in Manchester, I May 1959, in The Manchester Guardian, 17 April 1959, p. 5. Courtesy of CND. Rec. Acq. I,203.

"Nuclear War". Ts.; 8 leaves, prepared by Christina Foyle of BR's speech at Foyle's Literary Luncheon, 23 Nov. 1961, to launch Has Man a Future? (AI2I) the same day. Courtesy of Christina Foyle. Rec. Acq. I,176.

"A New Approach to Peace". C64.43. Fax of ts.; 9 leaves. In The Minority of One, 6, no. 6 (June 1964): 6-9, and Russell, n.s. Is (summer 1995): 7-20. Courtesy of Ramesh Krishnamurthy at the Linus Pauling papers, Oregon State U. Rec. Acq. I,I84. 